\title{
Opinion 59
}

\section{Designation of NCIB 11664 in Place of ATCC 23767 (NCIB 4112) as the Type Strain of Acetobacter aceti subsp. xylinum (Brown 1886) De Ley and Frateur 1974}

\author{
Judicial Commission of the International Committee on Systematic Bacteriology
}

The Judicial commission designated NCIB 11664 as the type strain of Acetobacter aceti subsp. xylinum in place of strain ATCC 23767, which is a Gluconobacter sp.

Gillis et al. (6) presented convincing evidence that the type strain of Acetobacter aceti subsp. xylinum (ATCC 23767) (3, 4) recorded in the Approved Lists (8) is not a member of the genus Acetobacter. The results of studies on strains ATCC 23767 and CIP 57.14 (both subcultures of NCIB 4112 acquired in 1968 and 1957, respectively) and on strain NCIB 4112 showed that all three strains, although identical, are cultures of Gluconobacter oxydans, not of Acetobacter (5, 6). After investigating the histories of these strains, Gillis et al. (6) suggested that the stock culture was mislabeled or contaminated sometime between 1933, when Bertrand deposited the organism in the National Collection of Type Cultures, and 1957.

The results of an examination by Gillis et al. (6) of a Sordelli-dried preparation, dating from 1949 and temporarily designated NCIB 4112B, showed that this strain was phenotypically identical to the bacterie due sorbose isolated and described by Bertrand $(1,2)$. The National Collection of Industrial Bacteria has decided to keep both strain NCIB 4112 and strain NCIB $4112 B$ and to use the following designations: NCIB 11301 ( = NCIB 4112), now known to be a culture of Gluconobacter oxydans (5); and NCIB 11664 (= NCIB 4112B), the authentic Bertrand strain, a member of the species Acetobacter aceti subsp. xylinum.

Gillis et al. (6) requested that the type strain of Acetobacter aceti subsp. xylinum recorded in the Approved Lists (8) as ATCC $23767(=$ NCIB $4112=$ NCIB $11301=$ CIP 57.14) be replaced by strain NCIB 11664 (= NCIB 4112B) according to Rules $18 \mathrm{~g}$ and $18 \mathrm{i}$ of the revised Bacteriological Code (7).
The Judicial Commission considered the request and unanimously approved the following opinion.

Opinion 59. The type strain of Acetobacter aceti subsp. xylinum is NCIB $11664(=$ NCIB 4112B) not ATCC $23767(=$ NCIB $4112=$ NCIB $11301=$ CIP 57.14).

\section{LITERATURE CITED}

1. Bertrand, G. 1896. Préparation biochimique du sorbose. C. R. Acad. Sci. 122:900-903.

2. Bertrand, G. 1898. Recherches sur la production biochimique du sorbose. Ann. Inst. Pasteur (Paris) 12:385-399.

3. Brown, A. J. 1886. On an acetic ferment which forms cellulose. J. Chem. Soc. Trans. 49:432-439.

4. De Ley, J., and J. Frateur. 1974. Genus Acetobacter Beijerninck 1898. 215, p. 276-278. In R. E. Buchanan and N. E. Gibbons (ed.), Bergey's manual of determinative bacteriology, 8 th ed. The Williams \& Wilkins Co., Baltimore.

5. Gillis, M., and J. De Ley. 1980. Intra- and intergeneric similarities of the ribosomal ribonucleic acid cistrons of Acetobobacter and Gluconobacter. Int. J. Syst. Bacteriol. 30:7-27.

6. Gillis, M., K. Kersters, F. Gosselé, J. Swings, J. De Ley, A. R. MacKenzie, and I. J. Bousfield. 1983. Rediscovery of Bertrand's sorbose bacterium (Acetobacter aceti subsp. xylinum): proposal to designate NCIB 11664 in place of NCIB 4112 (ATCC 23767) as the type strain of Acetobacter aceti subsp. xylinum. Int. J. Syst. Bacteriol. 33:122-124.

7. Lapage, S. P., P. H. A. Sneath, E. F. Lessel, V. B. D. Skerman, H. P. R. Seeliger, and W. A. Clark (ed.). 1975. International code of nomenclature of bacteria. 1975 Revision. American Society for Microbiology, Washington, D. C.

8. Skerman V. B. D., V. McGowan, and P. H. A. Sneath (ed.). 1980. Approved lists of bacterial names. Int. J. Syst. Bacteriol. 30:225420. 